\title{
SEDUCTION AS INSTRUCTION: THE FEMALE AUTHOR AS PYGMALION IN LONG EIGHTEENTH-CENTURY QUIXOTIC NOVELS
}

\author{
Miriam BORHAM-PuYaL \\ University of Salamanca \\ miriambp@usal.es
}

\begin{abstract}
Don Quixote played a crucial role in the shifts in taste and ideology that occurred during the long eighteenth century, being an instrument for authors to validate their own work in contrast with the production of others. New didactic works displayed the need to overcome the romantic supersystem that previous authors offered and even the patriarchal or colonial canon that had been established. The present article will focus on two women writers, Tabitha Tenney and Mary Brunton, who with a story of literary and literal seductions raised their pens against a non-questioned romantic integration in didactic novels and who even converted prior canonical cervantean authors in the origin of their heroines' quixotism.
\end{abstract}

Keywords: Quixotism, mimetic reading, intertextuality, didactic novels, women writers, literary criticism. 


\title{
SEDUCCIÓN COMO INSTRUCCIÓN: LA AUTORA COMO PIGMALIÓN EN NOVELAS QUIJOTESCAS DEL LARGO SIGLO XVIII
}

\begin{abstract}
RESUMEN. Don Quijote ha jugado un papel fundamental en los cambios estéticos e ideológicos que tuvieron lugar en el largo siglo XVIII al convertirse en un instrumento en manos de diferentes autores para validar su trabajo artístico en contraposición a la producción de otros. Nuevas novelas didácticas alegan la necesidad de superar los suprasistemas románticos que ofrecen otros autores e incluso el canon patriarcal o colonial que se había establecido. En concreto, este articulo se centrará en dos novelistas, Tabitha Tenney y Mary Brunton, quienes desarrollan una historia de seducción literaria y literal para alzar su voz contra una indisputada integración romántica en novelas didácticas, y quienes incluso convierten a los anteriores autores cervantinos en el origen del quijotismo de sus protagonistas.
\end{abstract}

Palabras clave: Quijotismo, lectura mimética, intertextualidad, novelas didácticas, escritoras, crítica literaria.

Received 16 January 2017

Revised version accepted 20 July 2017

\section{INTRODUCTION}

Eighteenth-century Britain is an important time and place to understand the impact Miguel de Cervantes' masterpiece has had on literature outside Spanish borders. ${ }^{1}$ At this time, Don Quixote came to play a crucial role in the shifts in literary taste and morality, being an instrument in the hands of very different authors to validate their own work to the detriment of others. The undeserving works object of such an attack were, in the former authors' opinion, aesthetically or morally inadequate, or even unquestionably pernicious for their readerships. Under the pen of these literary emulators, the quixote became a reader deluded by the latest literary craze, whether Gothic romances, sentimental novels or even Scottish historical novels, who was in need of some form of cure. ${ }^{2}$ Ironically, this antidote was administered through the same means by which they had become quixotic in the first place: literature. Reading became, thus, an important ideological and educational tool, the source of both madness and the restoration to one's senses. This metaliterary comment on reading evinced the immense power of the written word as it echoed the concerns of contemporary moralists on the effects the uncritical perusal of certain books could have on the shaping of a young reader's beliefs and notions of the word.

\footnotetext{
1 See Brean Hammond (2009); Wendy Motooka (1998); P.J. Pardo (2007) or P.J. Pardo (forthcoming). 2 See Miriam Borham-Puyal (2015).
} 
Throughout the long eighteenth century, many novelists faced the recurrent accusation of being, in fact, seducers who aimed to entrap young readers, a fact which placed the latter in a quixotic position. Although "all genres of reading" could "upset some commentator in this period", romance, as happened in Cervantes' novel, is perceived as a particularly dangerous genre, in this case owing to its attraction for young women readers (Pearson 1999: 43, 82). At this time, it was feared that the implied female reader concluded her reading immersed in the fictional world, sympathising and/or identifying herself with the heroine of romance who lived extraordinary adventures and obtained her happy ending. Consequently, the quixotic reader aimed to translate the epistemological system of her romances into the real world she inhabited, in order to culminate in the world outside the text the desire that she, unlike the textual heroine, could not fulfil at a diegetic level.

Given that romances implied such a danger for young women readers, authors declared that their texts had been written to counteract this risk by developing a metaliterary game which exposed the dangers of certain genres or modes of reading. Hence, innumerable works were published in which a young woman had her perception of the world altered by an excessive perusal of a particular genre or author and, subsequently, started to act in the real world according to the semiotic code acquired from her obsessive reading. Her delusion would be twofold. On the one hand, it would be epistemological in nature, as she will believe that what is impossible can come to be, and, on the other hand, it would be axiological, as the quixote could develop new ethical principles based on her readings (Pardo 2005: 358). The awakening of the quixote would address both forms of delusion and the consequences in these novels varied from the most tragic to those ridiculously comic. Quixotism became, thus, an instrument for certain aesthetical theories and ideologies that employed the novel with didactic purposes to criticise those works of fiction which were considered implausible or immoral, a criticism that could be found in the original work by Cervantes. The quixotic novel was indeed the perfect vehicle to become a literary critic and to validate one's stance as a writer, both in matters of genre and even gender, with well-known women writers of their time, such as Charlotte Lennox, also writing in a cervantean manner in her renowned The Female Quixote, or the Adventures of Arabella (1752) (Borham-Puyal 2015: 39-70). ${ }^{3}$

Notwithstanding the claim that those novels constitute an antidote to the literary venom that poisons the mind of readers, most of these didactic texts display the same objective: to somehow seduce their audience so that their readers adopt what has been termed the text's "narratorial ideological supersystem" (Wood 2003: 66), ${ }^{4}$

\footnotetext{
3 In this chapter the author explains Lennox's response to prior literature, including Richardson's and Fielding's.

4 In her analysis, Wood employs Susan Rubin Suleiman's use of the term "ideological supersystem"
} 
understood as the novel's moral or political basis. The defence of such supersystem, or the sustainment of the reader's interest in it, required authors to develop certain strategies of authorial control that implied a thorough rhetorical execution, for example, in the use of narrative voices or prefatory material (66). In Wood's words, authors employed these strategies to underscore the "lessons taught by the narrative" (66); however, it could be argued that they did so while building enough empathy for heroine and author alike to ensure that the faithful readers would continue to buy similar novels by the same author. That is, the audience is once again expected to become malleable in its convictions, but also in its taste. In this line, it could be stated that some of the most representative authors of novels in England, and, more specifically, of relevant mid-century didactic novels, seek to achieve what has been termed "absorptive reading" and an extreme "automatic imitation" (Warner 1998: 213-214). In particular, Samuel Richardson claimed that the instruction he had devised by means of his moral precepts in Pamela (1740) exonerated him from the charge of promoting the same kind of seduction among his readers as that fostered by romances. However, his prescriptive generalizations still call for the application of his semiotic code to the reader's experience. Therefore, the author still assumes a great influence over his readers. Richardson and his reader become, respectively, pygmalionic mentor and literary Galatea (Raff 2006: 466). Ironically, then, the ideal reader of this kind of didactic fiction could be a quixotic one.

Moreover, despite his criticism, Richardson employs the same romance he condemns to achieve that particular attraction over his devoted readers. In this sense, the instruction/seduction that the novel exerts over the reader is allegorically reflected in the literal and literary seduction that Pamela undertakes with $\mathrm{Mr}$. B in the novel (Raff 2006: 474). Mr. B concludes the novel seeing the world as Pamela does, and acting according to her romantic principles, in the same manner Richardson's devoted readers would adopt his supersystem, transforming him into the epitome of the moral novelist that would become so popular in the mid-eighteenth century. Pamela's use of the romance to build her own story -her "romantic emplotment"- within the frame of the novel is an instrument that enables Richardson to write a work morally imbued with the high ideals of romance at the same time that he creates a work of fiction in which the romantic and realistic narratives are in constant dialogue, evincing his nature as a cervantean writer (Pardo 1996: 331). Both, Pamela and Richardson, employ romance to seduce their readers for moral purposes, as well as to obtain more material objectives: marriage and publishing success, respectively.

(1993: 76). The concept of the "supersystem" is better known in the fields of engineering, architecture, or even medicine, where it could be defined as an organic whole; a definition that befits the notion of a moral or aesthetic message that supports the whole text. 
Richardson's influence is undeniable. However, well-known dissenting voices were also raised, among them Henry Fielding's, who, with Shamela (1741) or Joseph Andrews (1742), highlighted the consequences of becoming a victim of Richardsonian quixotism, that is, of the application of the romantic code of his novel in real life. In contrast with Richardson, Fielding, employing parodic and metanarrative techniques learnt once more from Cervantes, advocated his own ethical and aesthetic discourse about what the novel should be, and awoke his readers from their quixotic absorption and imitation. Nevertheless, Fielding himself develops in Tom Jones (1749) a romantic plot similar to Pamela's, at least in one matter: the final romantic wedding to conclude the plot of the reformed rake turned ideal husband. Somehow, in this work romance triumphs in an anti-romantic context, characterized by its realistic and picaresque nature (Pardo 2006: 82-83). While in Don Quixote the romantic vision is crushed or relegated to secondary stories, in Fielding's novel the romantic plot is validated. Jones and Pamela, therefore, share their romantic destiny and, more relevantly, the fact that their happy ending somehow sanctions a romantic vision of reality.

The triumph of this vision will cause other didactic works to display the need to overcome the romantic supersystem that these authors offer and the canon by which Richardson and Fielding become the moral and literary models to imitate. That is, new novels will aim to seduce their readership into new forms of what could be termed moral aesthetics, the taste for a particular genre that also reflects a certain approach to the world from a political, cultural or religious point of view. Authors would then appropriate what made Richardson so popular -his equation of formal realism with what was later termed his "moral realism" (Ballaster 1992: 198)5-, would scrutinize his works or Fielding's under it, and would find them wanting. In particular, the present article will focus on two women writers who, with a story of literary and literal seductions, will raise their voices against that non-questioned romantic integration in didactic novels and who will convert those cervantean authors in the origin of their heroines' quixotism, placing them at the core of their own comment on fiction and the power of reading. By so doing, they would become literary critics who would also challenge the canonical status of these two authors and propose an alternative form of didacticism and dialogue with romance.

Reading for these authors was a politically and morally charged activity, for you could become what you read. As conservative women writing in America and Scotland, respectively, they would, hence, oppose the patriarchal and colonising influence of these epitomes of British middle-class writing. From their perspective, reading was best put to use if it enabled young readers a safer transition into

\footnotetext{
5 As Ballaster explains, in Richardson's works "formal realism had come to be equated with moral realism," therefore "the accusation of improbability had come to stand for that of immorality" (1992: 198).
} 
the society in which they lived, rejecting romantic or foreign notions on virtue, marriage, or social climbing, which were perceived as particularly dangerous for young women. Therefore, their novels aimed to expose the effects of unquestioning adherence to literary values foreign to their own. In addition, they would prove that no text was safe from developing a quixotic audience, not even their own novels, unless those readers were educated to become critical thinkers that were aware of the aesthetic and moral limitations of the textual worlds they tried to inhabit in real life. Ironically, this awareness would be raised by recurring to the same author that had inspired Richardson and Fielding themselves, Cervantes.

\section{TABITHA TENNEY AND THE DANGEROUS NARRATIVE OF THE OLD WORLD}

In the awakening of the new American nation, politics and literature fed their respective discourses with the adoption of certain topoi from Richardson's works. ${ }^{6}$ As the virtuous woman, the Republican wife and mother, become the emblem of the developing nation, the over-zealous but cunning virgin or the fallen woman gained importance in literary, cultural, moral and political messages. ${ }^{7}$ At this time, moralists and authors develop the same debate on the novel and its appropriateness which had taken place in Britain some years before, especially concerning women. While there would still be dissenting voices which absolutely condemned fiction, American novelists would often defend the inclusion of reading in any educational programme undergone by young women. In order to support this last argument, novelists would adopt the self-condoning argument of the need to counteract the poison with its own appealing form. Once again, romance would be under attack, and it would become intertwined with the plot of seduction: once the young reader's fancy was inflamed, the rake had only to employ her delusion to his advantage. In opposition to romances, the novel would respond to a more "truthful" and hence "useful" representation of reality, which would in turn answer to the New England Puritan heritage (Mulford 1996: xxi). Novels could therefore counteract the extravagant, old-fashioned and morally questionable notions epitomised by romance. In addition, for American authors, as for British ones before them, romance would appear as something foreign and subversive to their own nationalistic and moral values. However, it is not only romance, but

\footnotetext{
${ }^{6}$ Some of President John Adams' statements include the following: "Democracy is Lovelace and the people are Clarissa [...]. The artful villain will pursue the innocent lovely girl to her ruin and her death," while early novels such as William Hill Brown's The Power of Sympathy: or, The Triumph of Nature, Founded on Fact (1789) and Hannah Webster Foster's The Coquette; or, The History of Eliza Wharton; a Novel; Founded on Fact (1797), develop a plot based on the seduction and ruin of a young reader. See Miriam Borham-Puyal (2013: 356-372).

7 See Eva Bannet (2000); Linda Kerber (1976); or Jan Lewis (1987).
} 
also novels which can be associated with foreignness and moral decay. Novels imported from Britain were considered to be dangerous for the emblem of the status quo, female virtue. Quixotic women are then conceived as cautionary figures who appear misguided in their mimetic approach to literature. Yet, it is not the fact that they mimetically reproduce what they read that is dangerous, it is the unsuitability of the models they have chosen which renders them aliens to their own society and, finally, ineffectual citizens (Brown 1999: 259). Given this fact, there could be a hope of curing the female quixote by developing a plot in which the quixote's senses were restored and she was happily accepted within a society again congenial with her own expectations. That is, early American quixotic fiction searched for a positive pattern of female development that reinforced the discourse of unity and uniformity as this new society emerged, so "ultimately quixotic mimeticism leads to social mimeticism, with the quixotes joining and affirming a common reality" (Brown 1999: 260). Therefore, one form of seduction and imitation replaces another, one model of female conduct replaces a previous one.

In this sense, even the epitomes of British moral narrative fiction could appear as the source for the delusion and ulterior ruin of the young readers portrayed by American authors. For instance, the American poet John Trumbull wrote in 1773: "Harriet reads, and reading really/ believes herself a young Pamela" (qtd. in Brown 1999: 251). The main problem of believing oneself a Pamela or a Clarissa, the most recurrently mentioned literary female models, was that women could "forget the circumstances of life in America" (Brown 1999: 251). The foreign narrative fiction American quixotes read leads them to fantasise about a self and a society that is not in accordance with the one in which they live. Although the political implications are subtly conveyed in the threats women's loss of virtue has for their families and their estate, the novels revolve around feminocentric plots of courtship and seduction and how their quixotic delusion ultimately enables their fall. These novels recurrently establish the connection between female virtue and reading, and how literary seduction may preclude a physical one.

In this scenario, Tabitha Tenney (1762-1837), author of a conduct book for young women and wife of a senator, published her novel Female Quixotism: Exhibited in the Romantic Opinions and Extravagant Adventures of Dorcasina Sheldon (1801). From the very title, Tenney states her intention of emulating Don Quixote. In the preface, she introduces the idea that Cervantes' novel, like her own, was written for the benefit of their readers, so that by looking into the mirror of fiction they could avoid the fate of the quixotes portrayed in them. From the very start, then, she plays the role of mentor to her readers. Adopting the role of a "compiler", in an epistolary preface addressed to "all Columbian Young Ladies, Who read Novels and Romances", the narrative voice states that she is merely repeating Dorcasina's own 
account of her adventures "for the advantage of the younger part of her sex" so that by observing the destructive effects of novels and romances on Miss Sheldon they "may avoid the disgraces and disasters that so long rendered her despicable and miserable" (3). Moreover, she hopes they will read it also for her own sake an as author. Tenney then uses a persuasive appeal to engage her readers' attention, both for her own publishing success and their moral growth. The strong terms in which she condemns the effects of Miss Sheldon's reading of novels ironically highlights the fact that she is recommending to peruse yet another novel to be cured from such dangerous addiction. In this sense, Tenney plays with the idea of a Richardsonian realistic prose, by asserting that her novel is something different: not "a mere romance", but rather a "picture of real life" (3). And still, she then explicitly links her novel to Cervantes' masterpiece and to his own metaliterary game involving a compiler and an alleged truthful biography of the knight: "when you compare [this novel] with the most extravagant parts of the authentic history of the celebrated hero of La Mancha, the renowned Don Quixote, I presume you will no longer doubt its being a true uncoloured history of a romantic country girl, whose head had been turned by the unrestrained perusal of Novels and Romances" (3). Tenney's intention is thus to present a tale as didactic and realistic as possible, while highlighting the fictionality of her own production and warning her audience from the very beginning that what they hold in their hands is just fiction written in a realistic manner, but fiction, nevertheless. She follows Cervantes' formula of writing a realistic novel that parodies romance and highlights its dangers, while avoiding those dangers in her own fiction by exposing that is it merely a construction. In addition, she employs the cervantean filter of a compiler or narrator to gain distance from the absorbed readers and control over that parody. Instead of having Dorcasina retell her story, as Pamela does, Tenney builds a strong narrative voice that is heard throughout the novel, from the preface to Dorcasina's final recantation from her quixotic folly.

In a clearly cervantean manner, then, Tenney describes the quixotic adventures of Dorcas Sheldon from her adolescence to her old age, and focuses on her obsession with British sentimental novels, in particular Richardson's, and on her enactment of the romantic plots she finds in them. Dorcas is a true quixote: she changes her name to Dorcasina, and dresses and acts in the fashion of romantic heroines, despite an unfavourable appearance; she has a Panzaic companion in her faithful Betty, who also becomes immersed in her lady's quixotism; and, above all, she undergoes innumerable jocular adventures in which her deluded vision of the world transforms her into a victim not only of her own illusion, but also of the manipulation of others. She constantly falls in love with whom she perceives as romantic heroes, and rejects an American suitor sanctioned by her father for being too un-romantic. In the end, Dorcas never marries and concludes the narrative single and disappointed. 
Throughout her comic and at times sad quixotic story, Tenney aims to criticise both the aesthetic and moral qualities of Dorcasina's readings and to provide an alternative. By including and subverting the romantic elements found in previous fiction, she parodies a wide range of situations common to romances which are also employed in eighteenth-century British narrative fiction; that is, she mocks any element which she perceives as implausible, ridiculous or condemnable, often highlighting the similarities between romance and the new species of fiction that had been developed. Imitating as well the episodic structure of Cervantes, Tenney builds a parodic gallery of mock lovers and romantic situations -such as amorous encounters in solitary woods, kidnappings, elopements, cross-dressing, secret correspondence, or fake identities-, which highlight the implausibility of the literary models adopted by Dorcasina, as well as the lack of morality displayed by some of them. These literary sources are easy to identify, as Tenney's text brims with direct allusions to British novels: from references to the title of some of Dorcasina's readings, such as Tobias Smollett's Roderick Random (1748), to the employment of names taken from Richardson's novels. Very early in the novel, for example, Dorcasina names the daughter of her neighbours "Harriet Caroline Clementina, being the names of persons, whose history she had taken great delight in reading" (15), persons who happened to be the heroines of Richardson's Sir Charles Grandison (1753). More importantly, Richardson's or Smollett's characters are employed by the female quixote as example to sanction her conduct, including Harriot Byron, Sir Charles Grandison or Roderick.

Several are the passages in which Tenney parodies Richardson's work and places examples extracted from his novel in a more realistic context. For example, she includes and subverts a typical scene in British sentimental fiction: the kidnapping of the heroine, this time by a fake lover who only intends to have fun at her expense. After exchanging clandestine passionate love letters, Dorcasina agrees to meet her lover in the garden. She is then kidnapped and incarcerated in an isolated house, where she is given pen, ink and paper to write to her father, mirroring Clarissa's situation (134). Dorcasina's letter, full of sentimental clichés, parodies her predecessor's and exhibits Tenney's mock-sentimental tone. As she narrates her comic adventures in a serious mode, Dorcasina allows herself to flourish her language and sentiments as any other heroine before her: "As well might he have insisted that the loadstone should no longer attract the needle, as that the graces and virtues of O'Connor should cease to attract my fondest affections!" (135). The striking contrast of her situation and the nature of her lover with her flamboyant language highlight the artificiality of romantic prose and sentiment, while the scene also underlines the compromising situations in which women are placed in these novels. 
In addition to the mock-style, Dorcasina's reaction also defies the sentimental conventions of a languid and passive heroine, conspicuously present in Richardson (Bannet 2007: 563): she escapes through a window and walks for miles to arrive home. This adventure serves Tenney's parodic intentions well. Dorcasina, battered and bruised after her scrape, reflects on her experience in the following manner, comparing her circumstances with those of the heroine of Grandison:

[...] the very same accident has formerly happened to Harriot Byron, though she was, to be sure, rescued in a different manner; and Dorcasina's satisfaction would have been complete, had O'Connor chanced to have been her deliverer. Her vanity, which before needed no addition, was now raised to the highest pitch; and she began to think, if she thus killed people, at a glance, it would be her duty, whenever she appeared in public, to veil her charms. (140)

Once more, the disparity between the anti-romantic heroine and her romantic reading of the events clearly resembles Cervantes' ludicrous humour. Later in the novel, for example, Dorcasina will once more refer to Richardson's work when she finds herself pursued by two suitors and she exclaims that she is in the same position that Sir Charles Grandison was, with a double love (276). However, both are a delusion -one exists only in her imagination and the other one is her friend Harriet in disguise. Dorcasina, as Lennox's Arabella, has learned the vanity and self-centredness of romantic heroines -one of their greater defects according also to Lennox and a self-absorption that one could also ascribe to Pamela- even if in the case of Tenney's heroine this vanity is obviously misplaced.

Together with these references to Clarissa and Sir Charles, Tenney also parodies the romantic vision and plot that Pamela builds. First, when the increasingly quixotic Betty assumes that a gentleman has come to woo her instead of her lady. The maid justifies her illusion with the argument that "there has (sic) been such things in the world before now, as a gentleman's marrying a servant maid" (208), which, of course, is a veiled reference to Pamela. Secondly, Tenney takes her parody further and subverts the roles in Richardson's plot. John, a servant with whom Dorcasina falls in love, is expected to behave and speak as romantically as Richardson's heroine, but he is, more realistically, an uneducated and rustic servant who hilariously disappoints Dorcasina's expectations. John also aspires to marry above his position, but the change in gender and social status between seducer and seduced, together with the age and ugliness of the former, increases the humour of the ridiculous consequences such a relationship will have for both of them, as well as of Tenney's mockery of her predecessor.

This reference to John also serves to parody another British work. After her father's death, Dorcasina is confined to bed for a long time and the first sign of her 
recovery is when she asks for her novels. Having recently found Roderick Random, which had "lain untouched in her closet for more than twenty years", and having perused it with great avidity, she finds that the eponymous hero of Smollett's novel had, under the very same name of John Brown, lived with Narcissa as a servant only to finally marry her. From this she concludes that her servant, also named John Brown, "must likewise be a gentleman in disguise" (227). By taking the name of the servant from Smollett and certain elements of the plot from Richardson -such as Dorcasina's gift of her father's clothes to her servant, which imitates Mr. B's gift of her mother's clothes to Pamela- Tenney mocks both by means of her quixotic heroine. She also highlights the hypertextuality of said British novels, as the idea of a gentleman employing a disguise to be close to his beloved one is a well-known convention of historical romances. ${ }^{8}$ While mocking such idea, nevertheless, the parody also emphasizes the danger of such a union to Dorcas's state and reputation. Tenney would stress this fact by exposing her heroine to many inappropriate suitors who come from the Continent and who employ her literary delusions to take advantage of her, among them an Irish emigrant and a Francophile radical, who both echo the revolutionary tensions of the Old World.

As later Jane Austen would do, in all these examples Tenney places her quixotic heroine in a context similar to the ones found in her readings only to put them to the test of reality, of a more plausible development and outcome. Novels are, in consequence, mainly reproduced in order to demonstrate how different fiction proves from the more debased reality of Dorcasina's experience. Tenney's heroine, as Don Quixote, Joseph Andrews or Lennox's Arabella, believes she can conduct herself in society with her readings as guide and, consequently, she interprets the surrounding world and herself under her romantic epistemology and will ultimately stand corrected in a much harsher fashion than in prior quixotic narratives. The greater punishment contrived for her quixote is an indication that Tenney will not be as benevolent with the effects of romantic or sentimental readings as Fielding or Lennox had been. While the latter described an early awakening and a traditional happy ending for their quixotes -the marriage to the deserving hero-, Tenney's heroine reaches old age unrepentant and unmarried. Whereas she escapes the more terrible fate of an unsuitable wedding, Dorcas has still rejected her unromantic but sound American suitor, which would have been her equal in social status and values.

Her negative vision of the long-lasting effects of the wrong kind of reading explains why Tenney obviously wishes to detach her work from her British

\footnotetext{
8 In fact, the parody of such conventions is recurrent in many cases of female quixotism, being the most prominent Lennox's novel, in which Arabella also believes her gardener is a nobleman in disguise. For other instances of quixotic women believing their servants to be disguised gentlemen and acting in accordance, see Borham-Puyal (2013: 217-18; 233-34; 735).
} 
novelistic predecessors, both from a moral and an aesthetic point of view. On one occasion, Dorcasina and one of her fake beaux meet in the middle of the night, challenging paternal authority and all sense of propriety. At this time the narrator states that "it would require the pen of a Richardson to describe the ecstacy [sic], and raptures of this meeting: but as mine pretends to no such powers, they shall be passed over in silence" (85). Tenney aims to develop a more anti-romantic narrative, more strictly didactic, including parodies of Richardson's plots and style, to expose the dangers of his narrative and his validation of the romantic vision.

While reproducing the episodic structure and the rich gallery of rascals from Fielding as well as Cervantes, Tenney also detaches her work from the former's, underlining the impossibility of fulfilling Dorcasina's romantic aspirations: she does not become a romantic heroine in the end, nor do the rakes transform into knights in shining armour. In Tenney, as in Cervantes, romance dies as characters return to reason, and the consequences of quixotism, while also hilarious, are not as benevolent as in Fielding's comic romance. Tenney's didactic and realistic narrative, in this sense, comes closer to the Spaniard's anti-romantic novel. Even the subplots reinforce this overcoming of romance by means of the mocking of Betty's aspirations or the more prosaic courtship and marriage of the realistic Harriet, who has not lived up to her sentimental and literary name. Her courtship takes place without hyperbolic sentimental rhetoric or the romantic convention of several years of devotion, service and separations, and her marriage is characterized by real-life problems: little thefts from the servants, some financial penuries, etc. That is, despite the inclusion of a romantic perspective through her use of parody, Tenney, differently to her predecessors, never validates it and rejects it in favour of a clearly anti-romantic genre that seeks to awake both heroine and readers from their sentimental illusions. Her romantic quixote dies and a philanthropic heroine awakes at the end, and Harriet and the reformed Dorcas end the novel as two variants of the praised Republican model, the wife and the matron, for the benefit of Tenney's American readers.

Coherent with her didactic intent, her novel concludes with a letter of recantation from the heroine herself, where she states the errors in which she has incurred owing to her obsessive reading of fanciful novels and her resulting "ridiculously romantic and absurd conduct" (323). She compares her experience to a dream, a delirium, a shadow and a spell: all shattered by reality. She blames the authors of her readings, and, more specifically, "their fascinating influence on [her] young and inexperienced mind" for her misery (324). In this accusation Tenney, then, resumes the seduction trope at the same time she provides the antidote: "a taste for books of real instruction and utility" and a watchful eye on what little girls read, so that they will not adopt "false ideas of life", "illusory expectations" or become "ignorant of every thing really worth knowing" (325). This, of course, leaves the reader 
wondering about the worth of Tenney's own novel. The key is in Dorcas's final piece of advice to Harriet as a mother and instructor of her daughters: "Describe life to them as it really is, and as you yourself have found it, chequered with good and evil" (325), which is precisely what Tenney has attempted to do in her novel. This is the reason why Dorcasina returns to being Dorcas, or why it is Harriet who achieves her happy ending: what the reading Galateas have learnt is what life looks like and what is truly important from Tenney's moral point of view. Quixotic mimeticism is now social mimeticism, and Tenney has fulfilled her role as Pygmalion, emulating whom she saw as a great novelist and pedagogue, Cervantes. In addition, she has validated her own literary and moral authority. She has acted as a literary critic towards previous British fiction and has superseded her American female voice to that of previous male authors on what a woman's readings and conduct should be.

\section{MARY BRUNTON AND ROMANTIC EVANGELISM}

In the aftermath of the French revolution, quixotism in Britain became an ideological instrument to be used by both the Jacobin and anti-Jacobin parties. Quixotes became embodiments of the main principles of their adversaries' political agenda, and their cure meant the restoration to what authors from one side or the other considered reason. ${ }^{9}$ Just as it was in American novels, in the end the quixotes renounce their initial supersystem in order to adopt the one condoned by the novel. However, as the century progressed, this political use of a quixotic character was replaced once more by parodic appropriations that targeted different genres or authors. The reasons why these particular works of fiction were parodied or their authors satirised in quixotic fictions would vary: it could be owing to remnants of political criticism, to the lack of plausibility or quality found in them, to the purpose of highlighting a certain literary vogue that had taken over the market, or to the intention of exposing the moral dangers posed by certain readings (Wilson 2007: 39). All these motives are exemplified in works such as Eaton Stannard Barrett's The Heroine (1813) or Sarah Green's Romance Readers and Romance Writers (1810). These novels share a conservative discourse focused on the need to preserve the British status quo by defending traditional ideals and combating revolutionary ideologies. In particular, they return to the trope of an intellectual seduction preluding a physical one, and to the role of reading as an agent of madness or reason.

At this time, female virtue continued to be linked to the preservation of the state, the family, and the national church (Wood 2003: 36), and a highly ideologically or morally charged courtship plot permeated many novels as an emblem of the dangers of women's seduction by the wrong suitor. By developing a quixotic plot of literary

\footnotetext{
9 See Miriam Borham-Puyal (2012) and Matthew O. Grenby (2001).
} 
seduction, these two novels thus transform a young woman reader in the locus for the debate on politics, morality and literary taste. In both novels, romances, French fiction and Francophile pamphlets are the cause of their young characters' quixotism. Once more, inappropriate readings are associated with foreignness, with difference, with the wrong kind of mimeticism and its consequences. Both introduce villainous seducers who aim to use the young readers' delusion to ruin their reputations, a fall with disastrous results in Green's novel, while remaining only a threat in Barrett's. These two novels, moreover, use other readings as antidote to the quixotizing poison: Green portrays virtuous and wise readers that peruse moral novels and poetry, whereas Barrett employs Don Quixote as suggested healing text for his quixote, once more emphasising this idea that an implied quixotic reader might be cured by means of a diegetic one. In addition, they highlight the abovementioned idea that the quixote's fault was sometimes not being too mimetic, but failing to be mimetic enough when it came to the acknowledged ideology or code of conduct of the people around her. These novels will conclude with the integration of the heroine into her social circle, by returning to reason, to different forms of reading and to a condoned form of collective mimeticism. Barrett and Green seem to hope to offer better models of reading and behaviour, so that their own implied readers could have a mimetic model opposite the revolutionary or liberal one of the romances or novels that had triggered the character's quixotism at the start of the novel.

Writing at around the same time as these authors, Mary Brunton (1778-1818), a Scottish and Methodist novelist, publishes a relevant quixotic novel: Self-Control (1811). With it, she claims a place in the British cervantean tradition by introducing not one, but two quixotes, and by highlighting the dangers of any form of uncritical reading. Her intentions are clearly stated in her preface to Joanna Baillie. Speaking on the usefulness of her fiction, she claims: "If my book is read, its uses to the author are obvious. Nor is a work of fiction necessarily unprofitable to the readers. When the vitiated appetite refuses its proper food, the alternative may be administered in a sweetmeat [...] I am not without hope that [...] the avowal of a useful purpose may be an inducement to tolerate what otherwise might be thought unworthy of regard" (Brunton 1811: n.p). Throughout her work, Brunton will come back to the idea of reading as a disorderly appetite that needs to be provided with wholesome food, a recurrent topic in the moralistic discourse on reading. ${ }^{10}$ Her novel is then

\footnotetext{
${ }^{10}$ For example, in her 1802 novel The Infidel Father Jane West writes: "The rage for novel does not decrease; and, though by no means think them the best vehicles for 'the words of sound doctrine'; yet, while the enemies of our church and state continue to pour their poison into unwary ears through this channel, it behoves the friends of our establishments to convey an antidote by the same course; especially as those who are most likely to be infected by false principles, will not search for a refutation of them in profound and scientific compositions" (emphasis added, 1802: I, ii.). As shown in this example, conservative discourse built a series of metaphors to describe the differences between both
} 
presented as a remedy for poisonous and unprofitable fiction. To reinforce the moral cure that her fiction provides, Brunton will develop a contrast between her heroines' perceptions and that of the other characters, the narrator or even the implied reader. Similarly to the interplay between internal and external focalization that Austen would later master in her novels, Brunton shifts from her character's consciousness to the narrator's insightful comments to contrast the limited and the thorough knowledge they respectively hold; that is, this authoritative and at times very intrusive narrator is used to "indicate the appropriate readerly response" and to emphasise the ideological supersystem that reassesses the systems represented by the characters (Wood 2003: 66). Gaining control of distance, she achieves to detach both the implied reader's and the author's perception from her heroine's to evidence how deluded the intrinsically romantic and inexperienced heroine is. What Laura sees or perceives, then, is filtered and exposed to the informed scrutiny of the reader, who shares the omniscient narrator's complete vision of the characters' motives and desires and can learn from their mistakes.

These lessons in proper reading are developed by means of the abovementioned two quixotes. First, Brunton depicts a very obvious quixotic character, Julia Dawkins, an avid reader of novels, who interprets the world and acts according to the literary principles she has acquired. Julia is seduced by any novel, including those considered impeccably moral, or, more surprisingly, even by those that portray another female quixote seduced by sentimental literature, such as Jane West's well-known didactic novel A Gossip's Story (1796), as is made evident in the following description:

\begin{abstract}
Having no character of her own, Julia was always, as nearly as she was able, the heroine whom the last read novel inclined her to personate. But as those who forsake the guidance of nature are in imminent danger of absurdity, her copies were always caricatures. After reading Evelina, she sat with her mouth extended in a perpetual smile, and was so very timid, that she would not for the world have looked at a stranger. When Camilla was the model for the day, she became insufferably rattling, infantine, and thoughtless. After perusing the Gossip's Story, she, in imitation of the rational Louisa, suddenly waxed very wise-spoke in sentences-despised romance-sewed shifts-and read sermons. (I, 131)
\end{abstract}

This adoption of different supersystems or "models for the day" -an expression which also emphasizes the idea of passing literary taste- leads to a form of quixotism in which Julia literally and uncritically imitates the heroines of the novels she reads and, thus, assimilates the epistemological and axiological discourse of the author as the one that models her behaviour. Brunton, therefore, highlights that, no matter

kinds of novels, for instance, the contrast between novelistic poison and antidote, between foul and nurturing literary food (Wood 2003: 14-15). 
how morally proper a novel is -or how popular, as is the case of Burney's two bestsellers-, it can trigger some form of quixotism in its readership. The author's satirical humour in the description of Julia's close imitation of the languid behaviour, childishness or even extreme morality of heroines, continues in the conclusion of Julia's quixotic tale: "Miss Julia, having lately read the life of a heroine who in the capacity of a governess captivated the heart of a great lord, had been seized with a desire to seek adventures under a similar character; but finding that recommendations for experience were necessary to her admission into any family of rank, she had condescended to serve her apprenticeship in the tuition of the daughters of an eminent cowfeeder" (II, 73). With this unromantic setting challenging Julia's romantic expectations, it is easy to see how Brunton parodies popular plots of sentimental fiction and mentors her young readers towards a more critical approach.

Understanding quixotism as the adoption of certain generalizations of a literary origin and their application to everyday experience, Brunton's novel possesses a less obvious quixote, the heroine, Laura Mandeville, an exemplary woman and skilled painter. The novel starts with the young Laura receiving the attentions of her suitor, Hargrave, a voracious reader of romances and picaresque novels. This gentleman, instead of proposing, suggests making her his mistress. Horrified but still in love with him, Laura casts him out for a time, in which she expects him to reform. Throughout the novel, Laura must defend her honour from Hargrave's intrigues, until he kidnaps her and takes her to America. Laura escapes, first fleeing her confinement and then sailing alone down a dangerous river. Hargrave dies after clearing her reputation, and Laura marries the anti-romantic and moral De Courcy, a reader not of romances but of moral poetry, who has loved her from the beginning.

Echoes of Richardson's novels can be traced. To start with, Laura is an exemplary heroine whose virtue is endangered by Hargrave, in the manner of a Pamela or a Clarissa. Moreover, similarly to Pamela, Laura's art is, at the same time, her most intimate and exposed expression: her paintings are created in her study, a private and feminine space, although they are exhibited and open to interpretation, as are Pamela's romantic letters, which enable her reader and her suitor to know her intimately. Laura manages to reject Hargrave at first, but then her romantic or even pamelian vision makes her trust a reform and a future proposal of marriage. This is made obvious not only in the time frame she offers for his transformation, but also, more subtly, in her own artistic production. Laura portrays Hargrave as Leontine parting with his family to fulfil his duty. Representing Hargrave as a pater familias is a symbol of the romantic expectations Laura has. However, as the novel progresses, it is clear that the positive influence that Laura has over Hargrave will not be enough to produce the moral improvement of the rake that Richardson, and even Fielding, introduce in their respective novels. 
SEDUCTION AS INSTRUCTION: THE FEMALE AUTHOR AS PYGMALION IN LONG EIGHTEENTH-CENTURY ...

In this sense, Brunton also criticizes Fielding's romantic plot. For example, the painting in which Hargrave appears as Leontine triggers the following conversation:

"But why were you so offended, that I compared your Leontine to Tom Jones?-Is he not a favourite of yours?"

"Not particularly so," said Laura.

"Oh why not?-I am sure he is a delightful fellow-so generous-so ardent. Come, confess-should you not like of all things to have such a lover?"

"No, indeed," said Laura, with most unusual energy; for her thoughts almost unconsciously turned to one whose character she found no pleasure in associating with that of Fielding's hero.

"And why not?" asked Miss Julia.

"Because," answered Laura, "I could not admire in a lover qualities which would be odious in a husband." (I, 133-134)

This dichotomy between the lover and the husband that Laura claims, runs parallel to the one between inappropriate and appropriate readings and supersystems: Hargrave, the lover, represents romantic heroes and rakes, whereas De Courcy embodies the values of the realistic and moral poetry he reads and even lends Laura. Brunton is very obvious in this association. In a conversation in which Julia and Laura compare their favourite literary heroes, while the former mentions Lord Orville, Delville, Valancourt, Edward, Mortimer, Peregrine Pickle, and a list that "sounded like a page of the catalogue of a circulating library", Laura chooses Jane Porter's very moral Thaddeaus of Warsaw, a picture of man so perfect that her father says it can barely be considered natural (I, 136-137) -and a man who has much in common with De Courcy. On Hargrave, Brunton writes: "he, by accident, stumbled on a volume of Peregrine Pickle, which he devoured with great eagerness; [...] Hargrave could boast an intimate acquaintance with all the plays, with almost all the poetry, and [...] with all the myriads of romances in his mother tongue" (I, 85-86). In this passage, Hargrave is described as displaying a disorderly appetite for fiction that his mother failed to direct to "food wholesome and invigorating", providing her son instead with romances, novels and plays and mistaking "their intoxicating effect for the bursts of mental vigour". Brunton explicitly warns of the results of that course of reading: the young man is ruined, for a "taste for works of fiction, once firmly established, never afterwards yielded to the attractions of sober truth" I, 86). On the other hand, De Courcy reads The Pleasures of Hope: with other poems (1799), a well-reviewed work by Scottish poet Thomas Campbell, which combines sentimentalism with an exalted spiritual tone to discuss the matter of the triumph of 
hope over misery. Peregrine, by Tobias Smollett, and the poem are both by Scottish authors. In this case, the condoned or condemned readings have nothing to do with nationality, but with the type of principles offered by them.

This conclusion is supported not only by the respective literary tastes of the male characters, but by the constant parallelism that Brunton establishes between Jones and Hargrave in the first part of the novel. This comparison could mean that their end might be similar. However, Brunton states that her intention is very different to that of her predecessors when she claims that in this novel she "merely intended to shew the power of the religious principle in bestowing selfcommand; and to bear testimony against a maxim as immoral as indelicate, that a reformed rake makes the best husband" (Brunton 1819: xlii). As the novel unfolds, this didactic purpose supersedes the romantic plot of the reformed rake, and Brunton clearly aims to teach her otherwise rational heroine that to expect such a reformation is just as foolishly romantic a notion as any of Julia's sentimental readings of reality. Answering to criticism towards Laura's resilient feelings for Hargrave, Brunton writes: "It is alleged, that no virtuous woman could continue to love a man who makes such a debut as Hargrave. All I say is, that I wish all the affections of virtuous persons were so very obedient to reason" (xlix). As did the American novelists of the late eighteenth century, Brunton chastises her heroine's unruly desire for an unworthy object, but also plays with the acquired literary expectations of her implied female readers and exposes them as romanticallydeluded as Laura by her reversal of the romantic plot of the reformed rake. Their delusion, as hers, is caused by the adoption of a supersystem that cannot, and should not, be transferred from fiction to reality. In the same way Laura must awake to the impossibility of achieving her romantic hopes, Brunton's readers will see their own expectations thwarted when Hargrave not only fails to reform and marry Laura, but also commits suicide. Instead of the happy integration of romance within the anti-romantic reality of Tom Jones or Pamela, Brunton more radically denies the validity of these novels as axiological supersystems by which the behaviour of young women readers could be ruled. As an alternative to the romantic Hargrave, Brunton offers her very appropriate suitor: with a happy and uneventful marriage, Laura, as most female quixotes, renounces her mistakes and becomes an ideal role model within the new moral system that the author introduces in her fiction.

In addition, Brunton provides an aesthetic comment on romantic fiction. By assigning the most implausible passages in the story to those scenes that result from Hargrave's seduction plot, Brunton once more highlights the dangers of Richardson's incredible romantic plot, especially because of its inscription within an otherwise verisimilar narrative. Evoking Pamela's kidnapping and her attempt to run away, Brunton takes it to the extreme with Laura's imprisonment in America 
and her subsequent improbable escape down the river. Literary critics, and even Jane Austen, mentioned the extraordinary nature of these passages, which broke the image of realism. Brunton herself described it as a patch in a sober narrative (xlviii), which may indicate the parodic nature of such a hyperbolic allusion, its nature as a caricature, like the undiscerning imitations of the quixotic Julia.

And just as she did with Julia, Brunton highlights with Laura that sentimental fiction is prone to draw characters that come too close to a caricature. Another criticism, relating once again to Richardson and the romantic elements of his work, is the extremely idealized nature of his characters. Brunton writes:

\footnotetext{
"You have such strict notions," said [Julia], "that I see Tom Jones would never have done for you."

"No," said Captain Montreville, "Sir Charles Grandison would have suited Laura infinitely better."

"Oh no, papa," said Laura, laughing; "if two such formal personages as Sir Charles and I had met, I am afraid we should never have had the honour of each other's acquaintance." (I, 136)
}

While the morality of Sir Charles is unquestionable when compared with the more plausible but morally flawed character of Jones, the propriety of the former is so perfect that the action could not have even taken place. On the contrary, the narrator describes Laura as a prim and extremely moral character who, nevertheless, is not perfect as her ideas are contaminated by her romantic vision of the world. This vision manifests itself in how she reads about martyrs and would like to become one of them, or how her image of Hargrave is "a creature of her own imagination", an "ideal being" (I, 14). This romantic vision leads to a passionate love for Hargrave, which almost ruins her reputation and her chances to achieve the traditional fairy-tale ending of a happy marriage to the hero. Differently to Richardson, Brunton does not praise her character's romanticism nor does she use it to transform her rake, but rather develops a process to awaken her quixotic heroine from the romantic illusion that qualifies her. As part of her overcoming of romance, Laura makes mistakes that not only illustrate the lessons of the novel, but that also contribute to its psychological realism (Wood 2003: 129). Laura possesses a romantic notion of the world, the one displayed in mid-century moral novels, therefore she is fallible and must overcome her errors of judgement regarding her suitors and herself, anticipating the psychological realism of later coming-of-age novels and inscribing her in the tradition of female quixotism that scholars have traced from Lennox to Austen. ${ }^{11}$ What is more, this fallibility is

\footnotetext{
11 See Borham-Puyal (2015) and Elaine M. Kauvar (1970).
} 
not only more plausible, but it also allows her heroines to be more active and attractive characters, as it is that overcoming of their romantic expectations which enables the existence of a feminocentric story of personal awakening and success.

This use of Laura's foibles to give her visibility is emphasised in the final paragraph of the novel in which, as happens with most quixotic heroines, once she has been restored to respectability, she does not return to art, but to the unnarratable state of wife as "the tranquil current of domestic happiness affords no materials for narrative" (II, 296). Having concluded her toils and adventures, having learnt the value of her truly worthy lover, having reached her maturity, her narrative concludes in the accustomed way: in marriage and invisibility. Moreover, it ends in the habitual manner for quixotic plots of female development, with an overcoming of romance and the inscription within a different form of narrative. A narrative that paradoxically proclaims invisibility for virtuous women, but that hopes to gain visibility and popularity among its women readers for its author, also a woman, by providing them with an attractive surrogate heroine so they might live through fiction the adventures that they could not experience themselves without peril to their virtue (Ballaster 2000: 198). Being mimetic, then, means living romance only through Brunton's fiction but not applying it to real life. It means accepting the paradox of fiction and not believing that the extraordinary can survive the test of the everyday. The surrogate heroine or fictional self thus entertains and teaches, and Brunton's moral lesson is transmitted in a pleasing form that dialogues with romance, that resembles it or is nurtured by it, but which at the same time hopes to overcome its limitations or flaws.

This overcoming, as advanced above, is obvious when it comes to the heroes of the story. Hargrave, from his early association with romance and his embodiment of the implausible plot of the reformed rake, represents the form of fictional illusions that the young quixote must reject. On the other hand, De Courcy, with his connection to sentimental moral poems, his role as Laura's mentor, or his portrayal as a truly sentimental, domestic and moral hero, epitomises the didactic fiction that Brunton herself is developing. Moreover, he represents the type of novel that Brunton defends against criticism and aims to achieve: a narrative fiction that combines noble sentiments, lively descriptions, natural characters, unity of action and an irresistible moral; a probable story that conducts to "a useful and impressive moral lesson" (Brunton 1819: lxxiv). De Courcy represents all the good qualities Brunton hopes to find in a novel. Therefore, although Brunton's novel has much of the fable construction of Tom Jones, with her villains and heroes and her American adventures, and of the Richardsonian story of virtue miraculously preserved and rewarded, she hopes to achieve moral but full characters "like Miss Edgeworth's" (Brunton 1819: lxxiv). However, the tension between didacticism and naturalness is not completely 
resolved in this first novel, and Brunton's genius shines more distinguishably in her next work of fiction, which also conveys the dichotomy between virtue and pleasure, the domestic and the romantic, in an engaging bildungsroman heroine and plot.

In the light of these considerations, it is possible to state that Brunton does not radically reject romance as a genre, but rather, as Cervantes, Richardson or Fielding, she dialogues with it and uses romantic elements to develop a didactic purpose that she conceives as more appropriate than the one introduced by her predecessors. Combining the attractiveness of romance -the exemplary heroine, the story of female virtue put to the test, the adventures and unexpected turn of events, the happy ending-, with her wish to portray woman's character in detail, plus her own Methodist vision of reality, Brunton creates a new form of moral aesthetics, what scholars have termed an "Evangelical romance" (Wood 2003: 28), a highly didactic work enveloped in the pleasing form of a romance that seeks, once more, to put quixotic seduction and cervantean generic hybridism at the service of moral indoctrination.

\section{CONCLUSIONS}

Tabitha Tenney and Mary Brunton, then, have learnt the lesson taught by Cervantes: by means of a quixotic narrative you can have your cake and eat it too, you can become a literary critic and a validated author. Both prescribe a cure for poisonous reading by means of their own novel, hoping to achieve a new form of mimeticism. Dialoguing with Cervantes and his heirs, Richardson and Fielding, through the quixotic illusion of her heroine, Tenney becomes not only an important link in the tradition of female quixotism, but also a novelist that deserves the title of cervantean. Her evocation of Cervantes himself, the parallelisms with his novel, and her obvious parodic intention evince the influence of Don Quixote, especially in its critique to literary antecedents. By means of her quixotic fiction, with its generic and gendered, aesthetic and moral, dialogue with the sentimental novel written by British authors, Tenney builds a form of fiction perceived as more realistic, returning to its cervantean origin.

Brunton emphasizes in her novels the danger implied in the fact that Richardson did not learn from Cervantes and did not cure Pamela's romantic aspirations. Brunton also criticizes Fielding for allowing a romantic, and in her terms somewhat immoral, ending in Tom Jones, in which the picaro and libertine Jones marries virtuous Sophia. From her point of view, it would seem that Richardson creates a narrative fiction as implausible as the amatory romances he so openly criticized, while Fielding is cervantean in his conception of the novel as an eminently antiromantic and realistic space, but allows the picaresque to overcome the moral 
idealism that romance enabled in Richardson's work. Brunton, with her hybrid prose and her Methodist discourse, preaches a genre at the same time antiromantic and anti-picaresque, uniting an aesthetic and moral purpose, although her formal experimentation finds itself limited by her didactic message.

Both authors become thus a link in the tradition of the reception and assimilation of Cervantes in literature written in English, creating quixotic fictions that dialogue with previous genres and authors to create a narrative they consider aesthetically and morally superior, and to warn their audience of the dangers of undiscerning reading. Of course, this validation of their own fiction and their obvious didactic ambition transform them in turn into pygmalionic figures that aim to sculpt their reading Galateas with their own moral, religious or artistic precepts. Their novels become, thus, possible targets of new quixotic fictions in the infinite game of mirrors that is the cervantean tradition.

\section{REFERENCES}

Ballaster, R. 1992. Seductive Forms: Women's Amatory Fiction from 1684 to 1740. Oxford: Clarendon Press.

Ballaster, R. 2000. "Women and the rise of the novel: sexual prescripts". Women and Literature in Britain 1700-1800. Ed. Vivien Jones. Cambridge: Cambridge University Press. 197-216.

Bannet, E. T. 2000. The Domestic Revolution. Enlightenment Feminisms and the Novel. Baltimore and London: the Johns Hopkins University Press.

Bannet, E. T. 2007. "Quixotes, Imitations, and Transatlantic Genres". EighteenthCentury Studies 40 (4): 553-569.

Borham-Puyal, M. 2012. "Reading Don Quixote as Political Agent: a Spanish Knight in British Ideological and Literary Wars". ES. Revista de Filología Inglesa 33: 7-25.

Borham-Puyal, M. 2013. Quixotic Readers and Quixotic Writers: Cervantes' Daughters in British Narrative Fiction from Lennox to Austen. Unpublished $\mathrm{PhD}$ thesis. University of Salamanca: Spain. <http://hdl.handle.net/10366/121340> (Accessed 5 May 2016)

Borham-Puyal, M. 2015. Quijotes con enaguas. Encrucijada de géneros en la narrativa británica del XVIII. Valencia: JPM Ediciones.

Brown, G. 1999. "The Quixotic Fallacy". NOVEL: A Forum on Fiction 32 (2): 250-273.

Brunton, M. 1811. Self-Control. Edinburgh: Printed for Manners and Miller.

Brunton, M. 1819. "Memoir". Emmeline, with some other pieces. Ed. Alexander Brunton. Edinburgh: Printed for Manners and Miller. 
SEDUCTION AS INSTRUCTION: THE FEMALE AUTHOR AS PYGMALION IN LONG EIGHTEENTH-CENTURY ..

Grenby, M. O. 2001. The Anti-Jacobin Novel. British Conservatism and the French Revolution. Cambridge: Cambridge University Press.

Hammond, B. 2009. "The Cervantic Legacy in the Eighteenth-Century Novel". The Cervantean Heritage: Reception and Influence of Cervantes in Britain. Ed. J.A.G. Ardila. London: Legenda. 96-103

Kauvar, E. M. 1970. "Jane Austen and The Female Quixote". Studies in the Novel 2: 211-221.

Kerber, L. 1976. "The Republican Mother: Women and the Enlightenment -An American Perspective". American Quarterly 28: 187-205.

Lewis, J. 1987. "The Republican Wife: Virtue and Seduction in the Early Republic". William and Mary Quarterly 44: 689-721.

Motooka, W. 1998. The Age of Reasons. Quixotism, sentimentalism and political economy in eighteenth-century Britain. London and New York: Routledge.

Mulford, C. 1996. "Introduction". The Power of Sympathy and The Coquette. Ed. Carla Mulford. London: Penguin. ix-lii.

Pardo, P. J. 1996. "Novel, Romance and Quixotism in Richardson's Pamela". Atlantis 18: 306-336.

Pardo, P. J. 2005. "La heroína quijotesca en la novela inglesa del siglo XIX: Jane Austen, George Eliot y otros novelistas". Cervantes y el ámbito anglosajón. Eds. Diego Martínez Torrón. Madrid: Sial. 356-375.

Pardo, P. J. 2006. "La tradición cervantina en la novela inglesa: de Henry Fielding a William Thackeray". Entre Shakespeare y Cervantes: sendas del Renacimiento.. Eds. Z. L. Martínez and L. Gómez Canseco. Newark: Juan de la Cuesta. 73-111.

Pardo, P. J. 2007. "El siglo de oro del Quijote en la literatura inglesa, 1740-1840". La buella de Cervantes y del Quijote en la cultura anglosajona. Eds. José Manuel Barrio Marco and María José Crespo Allué. Valladolid: Universidad de Valladolid, Secretariado de Publicaciones e Intercambio Editorial. 133-158.

Pardo, P. J. Forthcoming. "Don Quijote en el Reino Unido". Gran Enciclopedia Cervantina. Dir. Carlos Alvar. Madrid: Castalia. <http://hdl.handle. net/10366/118562> (Accessed 5 May 2017)

Pearson, J. 1999. Women's Reading in Britain, 1750-1835: a Dangerous Recreation. Cambridge and New York: Cambridge University Press.

Raff, S. 2006. "Quixotes, Precepts, and Galateas: the Didactic Novel in Eighteenthcentury Britain”. Comparative Literature Studies 43 (4): 466-481.

Suleiman, S. R. 1993. Authoritarian Fictions: The Ideological Novel as a Literary Genre. Princeton: Princeton University Press. 
Tenney, T. 1992 (1801). Female Quixotism: Exhibited in the Romantic Opinions and Extravagant Adventures of Dorcasina Sheldon. Eds. J. Nienkamp and A. Collins. Oxford: Oxford University Press.

Warner, W. B. 1998. Licensing Entertainment. The Elevation of Novel Reading in Britain, 1684-1750. Berkeley: University of California.

West, J. 1802. The Infidel Father. London: Longman and Rees.

Wilson, L. M. 2007. "British Women Writing Satirical Novels in the Romantic Period: Gendering Authorship and Narrative Voice". Romantic Textualities: Literature and Print Culture, 1780-1840 17: 24-46.

Wood, L. 2003. Modes of Discipline. Women, Conservatism, and the Novel after the French Revolution. Cranbury, London, Mississauga: Associated University Presses. 